DENIS ŠIPUŠ, Ph.D. student ${ }^{1}$

(Corresponding author)

E-mail: denis.sipus@fpz.hr

BORNA ABRAMOVIĆ, Ph.D. ${ }^{1}$

E-mail: borna.abramovic@fpz.hr

${ }^{1}$ Faculty of Transport and Traffic Sciences

Department for Railway Transport

University of Zagreb

Vukelićeva 4, 10000 Zagreb, Croatia
Transport Planning

Review

Submitted: 20 Mar. 2018

Accepted: 21 Sep. 2018

\title{
TARIFFING IN INTEGRATED PASSENGER TRANSPORT SYSTEMS: A LITERATURE REVIEW
}

\begin{abstract}
Designing tariff systems in public passenger transport is a complex issue of optimization by means of satisfying the wants and needs of all the engaged parties. An integrated passenger transport system (IPTS) stands for the concept of organization and management of public passenger transport based on a uniform tariff system. The issue of transport disadvantage of certain peri-urban and rural areas is the result of poorly organized transport systems. Social and spatial isolation in the framework of mobility is partly the fault of the way in which tariff systems have been designed with no regard to the social factors of the engaged parties for which such systems are designed - its users. Special emphasis in the research of tariff systems is placed on resolving issues of designing tariff zones, maximizing social welfare, transport equity, and transport disadvantage. An outline of the existing research and a review of literature concerning tariffs in integrated passenger transport systems is given, and proposals are put forward for future research due to the need for designing socially beneficial tariff systems, which would eliminate social exclusion, i.e., the transport disadvantage of individuals or parts of society.
\end{abstract}

\section{KEY WORDS}

tariff system; integrated passenger transport; zoning; social welfare; transport equity; transport disadvantage;

\section{INTRODUCTION}

Public passenger transport stands for the provision of a social service of transporting passengers from the point of origin to the point of destination. This ensures mobility of passengers on a regular basis using different means of transport operating on a clock-face schedule. An efficient public transport leads to a decrease in private vehicle use, which significantly contributes to the reduction of traffic congestions and pollution, thereby improving the quality of living.

One of the concepts of public passenger transport organization and management is an integrated passenger transport system (IPTS). It is characterized by the integration of various means of transport into a unified tariff system, a unified integrated clock-face timetable, and a unified ticket. The utilization of such a concept of organization and management would be beneficial to all the parties directly or indirectly included in the scope of the system. The parties directly engaged in the system are: (1) users, (2) transport operators, and (3) transport authorities, whereas the parties included in its scope are the ones that do not directly participate in the actual system but rather benefit indirectly from its advantages (reduction of traffic congestions, pollution, improved quality of living, etc.). IPTS is widely utilized in EU member states, where it has proven to be successful; its benefits are on the rise year after year [1]. It has been acknowledged in the most relevant European and national regulations and transport strategies as one of the measures of advancement of passenger transport mobility [2-5].

The uniform tariff system in IPTS is a set of principles based on which fares are offered for transport services provided by all operators included in the system. The design of such a system is characterized by the principles of uniformity, zonality, and degressivity. All methods of transport, that is, all operators, are included in the same uniform tariff system. The scope is determined by zones which are designated based on the size of the encompassed area and the features of the flow of passengers. When using tariffs, fare is degressive, i.e., it becomes proportionately cheaper with distance, meaning that passengers traveling longer distances will pay less than the ones traveling over shorter distances or crossing fewer tariff zones, regardless of price per kilometer. Therefore, it can be stated with some certainty that such a system is the backbone of a model for generating and distributing profit. It also determines the cost of fare for the provided service.

Tariff systems in IPTS determine the zones of the encompassed area based on which fares are calculated for the uniform transport service provided. The process of determining zones in tariff systems is referred 
to as zoning. Two issues arise from designing zonal tariff systems: (1) determining each zonal area - division of zones, and (2) determining the optimal fare.

The primary objective of defining tariff systems in IPTS is to increase its appeal, which would then increase the number of users of the transport service, thereby increasing income. In order to achieve that, users need to be addressed, as well as their purchasing power. The quality of the transport service and users' willingness to purchase it are determined by their willingness to use that method of transport. Maximizing the social benefit whilst determining the fares in tariff systems would lead to an increase of the appeal of using the IPTS services. Transport equity and care for peri-urban and rural areas would prevent their transport disadvantage and eliminate the need to utilize private vehicles for mobility.

\section{INTEGRATED PASSENGER TRANSPORT SYSTEMS}

Research in the area of population mobility is an essential part of transport science, whose aim is to improve the quality of living. Public transport (PT) plays a key role there since it leads to a reduction of traffic congestions generated using private vehicles. In order to improve the quality of transport service and attract and retain users of PT, steps are taken to design and implement an integrated public passenger transport system.

The first documented instance of integrated public passenger transport is found in Germany, Switzerland, and Austria, and the first implementation was achieved in 1965 in Hamburg. Statistical data show that the implementation of such systems into public transport contributes to the increase of users who turn to PT options at the expense of private vehicle utilization [6]. The concept of an IPTS is the latest and most up-to-date way of organizing and managing public passenger transport.

Common methods of transport, such as railway, bus, and tram, suffer from drawbacks due to the increase of the intensity of urban transport, which halt further developments of cities. An integration of transport modes is proposed with the aim of ensuring better coordination and synchronization in the public passenger transport [7].

It has been noted [8] that the PT coverage of rural areas is the key problem for the mobility of the population residing there. Even though developed countries usually aim to provide adequate PT options in peri-urban and rural areas as an alternative to private vehicle use due to pollution, the financial aspect poses a challenging question. Dividing the areas into urban, peri-urban, and rural is logically connected to population density, surface area, and infrastructural and morphological features. In less developed coun- tries, however, operators tend to keep only the most profitable lines running in order to maximize profits. A constant emigration from the rural areas has also been observed [9], as well as the need to invest in the transport sector in order to lay the foundations for a continuous long-term development of rural areas. The availability of PT, a quality line management, and the establishment of integrated transport systems in PT would help to improve transport equity, decrease rural exodus, and improve the overall quality of living in peri-urban and rural areas.

Kopecká and Švetak [10] place emphasis on a few prerequisites for implementing an IPTS. Doing so requires a certain level of transport demand in the targeted area. It is important to form the origin-destination matrix (OD) in order to observe the potential passenger journeys. The network line plan on the targeted area is organized in a clock-face schedule with railway lines which serve as the backbone of the traffic load. Apart from the aforementioned requirements, there is a need to synchronize the timetables and tariffs so as to be suitable for operators and PT users.

The points of integration of transport modes ensure a safe and smooth passage of passengers from one mode into another. The construction of bus terminals or their relocation next to railway stations is proposed in [11]. IPTS also requires good connections with private vehicle users, which can be achieved through the construction of park and ride systems and bicycle parking racks. Important integration points are park and ride systems fitted with safety devices that provide secure storage for private vehicles and bicycles.

The level of user satisfaction with PT services hangs on the features of the systems that provide such services but also on user expectations. Filipović et al. [12] define the quality of service as the ability of a service provider to meet all the demands and anticipated user needs. There are four aspects of the quality of service provision: (1) expected quality, (2) targeted quality, (3) actual quality, (4) achieved quality. Expected quality reflects the needs of users for planning, designing, and improving the service, i.e., taking into consideration the needs of users. The level of connection between user needs and the possibilities of providing services is defined as targeted quality. The actual quality is the level of services provided on a daily basis, whereas the achieved quality refers to the level of user satisfaction with the provided service. In their paper, Sumaedi et al. [13] define user satisfaction with the provided service as a latent variable, as it cannot be measured directly but only estimated using one of several indicators. The authors define users' satisfaction as a reflection of their mental image of the service which encompasses the symbolic understanding of specific products arising from the provided service. 
The tariff integration of various transport modes in the area encompassed by IPTS is considered to be the best financial option for passengers that switch between modes [14]. Research polls indicate that an IPTS, compared to regular public transport, is insignificant unless it provides them with shorter journey times and lower fares.

Research [15] has also shown that there is a wide array of stumbling blocks when introducing and implementing transport integration, classified as follows: (1) physical - planning and managing the traffic infrastructure, (2) logical - providing users with all the information needed, (3) economic - providing all the required technologies and regulations which determine the distribution of profit, (4) contractual - framework for rules of cooperation for all the engaged parties, (5) institutional and structural aspects of all the involved parties, and (6) judicial and regulatory aspects - integration between various modes of transport.

\section{TARIFF SYSTEMS OVERVIEW}

The reasons for research and reflections upon the models of tariff systems in public transport lie in the fact that they are both direct and flexible instruments which affect passenger behavior and reimbursement of costs. Empirical research has proven that user choices depend on several factors, first and foremost availability, journey time, possession of a private vehicle, discounted annual fares, and tariffs [8].

In practice, tariff systems are based on the calculation of the price per kilometer of the distance traveled, traveling across the defined zones, and journey time limitations.

Models for planning tariff systems in public transport aim to maximize: (1) demand, (2) income, (3) profit, and (4) social welfare. Several authors [16] propose in their research a non-linear optimization approach to tariff planning, based on a detailed discrete selection of user behavior. Four models are proposed which include different aspects whose adaptability depends on specific standpoints of planning. The simplest model of planning tariffs is the model for maximizing income based on specific user interests or political objectives. The second model is adjusted for maximizing profit and includes operational costs on the lines. It is safe to say that such a model represents the difference between the model for maximizing profit and operational costs on the generated journeys. The third model aims to maximize the demand for the transport service. Generally, previous research has defined demand within the context of passenger distance. Apart from the aforementioned models, there is also the model of maximizing social welfare. This refers to the sum of benefits of both providers and users. Operators benefit from the profit (income minus expenses), whereas users benefit from the difference between the generalized price acceptable to users and the actual generalized price users pay for the provided transport service. The impact of political, social, and external limitations when deciding on the model of tariff planning is highlighted as well.

Case studies in the cited research include the OD matrices for passengers traveling mostly on shorter distances, from 0.5 to 10 kilometers for public transport and private vehicle journeys. The latter do not include additional time needed for parking the vehicle and paying for it. The difference of price elasticity of single fares is also emphasized when compared to monthly passes, due to the assumption that monthly pass users are more sensitive to every price change. The developed models start from the assumption that all transport users have a private vehicle available, which ultimately leads to a higher competition between private vehicles and monthly passes than in reality. In fact, a number of permanent holders of a monthly or an annual pass do not own a vehicle and are thus less sensitive to fare price changes.

Huang et al. [17] argue that although traffic infrastructure is being invested in, many urban transport systems do not meet the needs of users. Fare revenues barely cover operational expenses, and most operators suffer losses and struggle to stay in the market. The underlying issue of regulating a socially beneficial tariffing is ensuring a financial balance between all operators and transport authorities. The authors point to the importance of interdependence of all participants when regulating tariff systems: (1) operator companies, (2) transport authorities, and (3) users. Transport authorities regulate the operation of tariffs and subcontract companies that provide passenger transport services. The authors noticed the discrepancy between defining tariff systems and frequency of departures and proposed a model for defining tariff systems which includes all the three parties (Figure 1). The importance of three-directional communication is emphasized: (1) transport authorities - transport operators, for the purposes of determining fares and subsidizing prices, (2) transport authorities - users, and (3) transport operators - users. The authorities see public transport as a public service and strive towards the maximization of social welfare. The operators, however, aim to increase profit in order to continue operating and maintain sustainable development, whereas users hope for the lowest possible price of the entire transport service.

Drdla and Bulíček [18] focus on the following important changes compared to standard tariff systems: (1) changes in the check-in technology, (2) introduction of flexible fares - tariffs in the regional coach transport, (3) introduction of uniform transport fares with time or zonal limitations. The authors emphasize the prerequisites of tariff systems in the IPTS which need to be met by the aims of every individual 


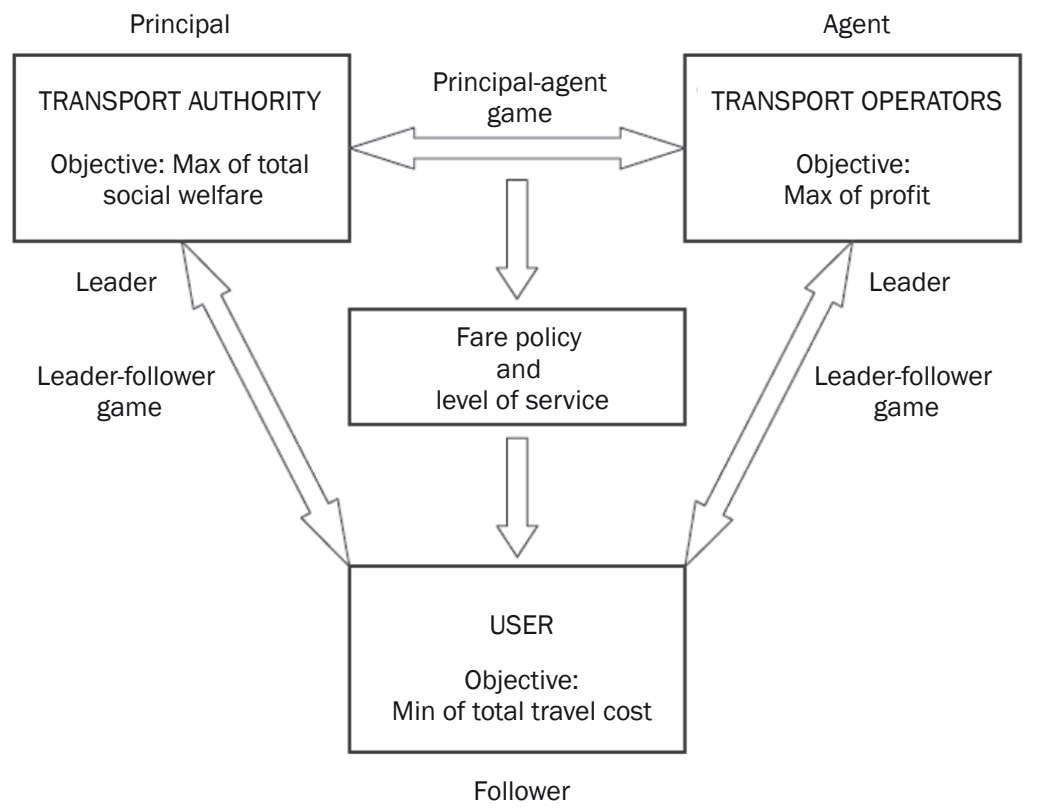

Figure 1 - The relationship between parties when establishing a tariff system Source: Adapted by the authors from [18]

party: (1) a simple and quick way of paying for services and checking-in in the system, (2) ensuring organizational requirements and the development of the IPTS, (3) ensuring a clear distribution of profit between the operators and checking the transport service impact, (4) gathering statistical data about the system (passenger dynamics, passenger number on certain lines, etc.), (5) improving the accessibility of public transport and ensuring the development of tariffs based on the optimal cost for the provided transport service, (6) reducing operational expenses (printing, distribution, transport document sales), (7) ensuring a high level of system security (protection against counterfeiting fares), and (8) reducing the number of non-paying passengers - passengers who have not paid the fare.

There are three tariff types used in IPTS: (1) zonal limitations, (2) a combination of zonal and time limitations, and (3) distance limitations (km). In the zonal tariff system, the area is divided into spatial zones all of which have a specific price, and proportionately to zone crossing, the fare increases. The combination of zonal and time limitations ensures additional limitation of the validity of the fare in accordance with journey time. Distance limitations are used in tariff systems that are based on the distance of the provided transport service.

Nowadays, contactless payment is increasingly used, and it is perfectly justifiable to include it in various tariff structures. Tariff systems with contactless smart cards enable the provision of relevant information about journeys, which affects fare calculation. Besides determining the fare, it is also possible to obtain data on station capacities. Smart card systems collect daily data on user movement and behavior ensuring the construction of satisfactory OD matrices [19]. There is a tendency for all passengers to use contactless cards in vehicles, which enables gathering data on the serial number of the card, name, and ID of the origin station, date and time of passengers boarding, and the number of transfers.

\section{THE ISSUE OF DETERMINING ZONES}

Designing tariff systems in IPTS is a relevant factor in understanding and motivating users on the one hand, but also operators and transport authorities on the other. Koháni [20, 21] lists several ways of designing tariff systems: (1) distance, (2) unit, and (3) zonal. It is emphasized that the distance tariff is fair, because users only pay for the actual distance traveled. Unit tariff systems have the same fares for the entire area and are usually utilized in city public transport. These are, however, not suitable for regional public transport since short journeys between two stations should not cost the same as longer journeys included in the regional public transport. The third system usually utilized in IPTS is zonal, which is the combination of the distance and the unit tariff systems. In such a system, the entire area is divided into several smaller areas, and the cost of the provided transport service is calculated based on the number of zones traveled. Two issues arise from designing zonal tariff systems: (1) determining the area of each zone - zone division, and (2) determining optimal pricing. A mathematical model for designing tariff zones was constructed based on the counting of zones which includes the parameters of modeling of the impact of price change on transport demand. Such a model focuses on the impact of 
changes in transport demand when designing tariff zones, and the distribution of stations throughout the tariff zone.

Zonal tariff systems are quite popular due to their simplicity and the availability of information and are therefore mostly utilized when designing tariff systems in IPTS. When designing the aforementioned systems, emphasis is placed on achieving zonal tariffs that are fair in traffic [22]. Fair zonal tariff systems stand for adaptation to the recommended price of the transport service which is generally considered fair, such as a distance tariff system. Such an approach demands from the transport operators an estimation of their profits.

Jansson [23] defines optimal transport service price as a sum of operator's marginal costs and marginal external influences on passengers, that is, the difference between operator's variable expenses and the time, in which the financial deficit runs.

\section{SOCIALLY WELFARE TARIFF SYSTEMS}

The questions that are often raised in research on IPTS are addressed by finding the factors that affect the willingness for utilization of such systems. Previous research has shown that three factors determine users' desire for utilization of such systems: (1) psychological, (2) operational, and (3) political. Psychological factors include the perception of public transport, marketing strategies, cognitive models, habitual actions, and behavior towards the environment. Operational factors include safety and protection, reliability, journey times, IT systems, issuance of transport documents, and tariff systems, as well as comfort levels. The political factors are comprised of the so-called push and pull strategies, legislation, economic reasons, information and education, and individual travel plans.

Chen et al. [24] point to the need for maximizing social welfare in transport by proposing models for determining optimal prerequisites that would ensure its achievement. The reason for that lies in the fact that passengers aim to reduce journey times and costs and increase the level of comfort, whereas operators strive towards maximizing their profits, and transport authorities try to minimize the total average journey time within the approximate constant demand or to maximize social welfare with regard to the elastic demand present. From the perspective of transport authorities, social welfare consists of the excess from the charged price and the profit from the transport operators.

The measures designed for maximizing social welfare and equity impose important changes in the entire tariff system and transport offer. First and foremost, this concerns the reduction of prices of transport fares and an increase of departures. These measures generate a higher financial deficit of operators and transport authorities due to a greater demand for subsidized public transport $[25,26]$. Problems arise with authorities with greater financial margins.

Transport has a substantial role in preventing social exclusion. The optimization of tariff systems grounded in social equality is an important stage of planning in IPTS. Research [27] has pointed out the importance of optimization of tariff systems for special groups of passengers such as: (1) youth, (2) people with disabilities, (3) women, and (4) the elderly.

The analysis of papers on transport planning in IPTS reveals the so-called transport disadvantage. Transport disadvantage is a process of putting an individual or a group of people in the position in which they assume disadvantaged social importance. Adequate mobility and accessibility are the fundamental prerequisites of today's society as a whole [28]. A disadvantage area is one in which the level of accessibility is not high enough to provide an uninterrupted access to everyday activities. The accessibility parameters are divided into the following: (1) spatial, (2) temporal, (3) financial, (4) environmental, (5) infrastructural, and (6) institutional. Taking into consideration tariff systems in an IPTS in the context of preventing transport disadvantage is an integral part of social policies and transport planning. It is evident that there is a lack of tariff system research from the standpoint of transport disadvantage, particularly the optimization of tariff systems in IPTS. Martens [29] insists on importance and duty of transport authorities to provide a fair planning and pricing of public transport services from the social and spatial viewpoints. It is essential to raise awareness of the need to achieve and ensure a sufficient level of mobility and accessibility for each individual, i.e., social group.

\section{CONCLUSION}

This paper examined existing research, providing a literature review on tariff systems in IPTS and brought forward proposals for future research. Notable shortcomings have been identified in the research of tariff planning and the need to optimize tariff processes. There is a need to design socially sensitive tariff systems which would eliminate social exclusion, i.e., transport disadvantage.

Different considerations of the tariff planning model are reflected in user wishes and operational costs of public transport service providers. Defining tariffs can significantly affect user behavior and their preference for a transport method, so it is necessary to plan tariff systems objectively so as to positively affect the transport demand. 
The tariff system design models mostly deal with urban areas, with little interest in peri-urban and rural areas. The reason behind this is the economic component that the latter cannot achieve due to small populations and lower demand for passenger transport.

The review of research literature on tariff systems in IPTS has also revealed issues regarding the wishes and possibilities of the most sensitive social groups. Mass exodus from rural areas is closely related to their reduced mobility. The analyzed papers place emphasis on the need to develop tariff systems of IPTS in the context of eliminating transport disadvantage. Defining tariff zones and designing optimal tariff pricing is a topic for further research from the standpoint of maximizing social equity and preventing transport disadvantage, i.e., exclusion of individuals or parts of society.

DENIS ŠIPUŠ, mag. ing. traff. ${ }^{1}$

E-mail: denis.sipus@fpz.hr izv. prof. dr. sc. BORNA ABRAMOVIĆ ${ }^{1}$

E-mail: borna.abramovic@fpz.hr

${ }^{1}$ Fakultet prometnih znanosti

Zavod za željeznički promet

Sveučilište u Zagrebu

Vukelićeva 4, 10000 Zagreb, Hrvatska

\section{TARIFIRANJE U SUSTAVIMA INTEGRIRANOG PRIJEVOZA PUTNIKA: PREGLED LITERATURE}

\section{SAŽETAK}

Dizajniranje tarifnih sustava u javnom prijevozu putnika predstavlja kompleksan optimizacijski problem usklađivanja želja i potreba svih dionika uključenih u sustav. Sustav integriranog prijevoza putnika predstavlja koncept organizacije i vođenja javnog prijevoza putnika temeljen na jedinstvenom tarifnom sustavu. Problem prometne marginaliziranosti pojedinih periurbanih i ruralnih područja javlja se kao posljedica loše organiziranih prometnih sustava. Društvena i prostorna izoliranost u kontekstu mobilnosti dijelom je posljedica načina dizajniranja tarifnih sustava u kojima se ne vodi računa na socijalne čimbenike dionika zbog kojih se takvi sustavi i dizajniraju - korisnika. Posebna pažnja u pregledu istraživanja tarifnih sustava u integriranom prijevozu putnika je usmjerena problemima dizajniranja tarifnih zona, maksimiziranja društvene korisnosti, prometne pravednost te prometne marginaliziranosti. Dan je pregled dosadašnjih istraživanja načina tarifiranja u sustavima integriranog prijevoza putnika te prijedlozi budućih istraživanja zbog uočavanja potrebe za dizajniranjem društveno korisnih tarifnih sustava u kojima bi se nastojalo eliminirati postojanje društvene isključivosti, odnosno prometne marginaliziranosti pojedinca ili dijela društva.

\section{KLUUČNE RIJEČI}

tarifiranje; integrirani prijevoz putnika; zoniranje; društvena korisnost; prometna pravičnost; prometna marginaliziranost;

\section{REFERENCES}

[1] Ernst, \& Young Savjetovanje d.o.o., Fakultet prometnih znanosti u Zagrebu. Elaborat prilagodbe organizacijske strukture operatera modelu integriranog prijevoza putnika; 2017.

[2] Vlada Republike Hrvatske. Strategija prometnog razvoja Republike Hrvatske za razdoblje od 2014. do 2030. godine; 2014.

[3] Gradski ured za strategijsko planiranje i razvoj grada. ZagrebPlan - Razvojna strategija Grada Zagreba, Ciljevi i prioriteti razvoja do 2020. godine; 2013.

[4] Zagrebačka županija. Županijska razvojna strategija Zagrebačke županije 2011.-2013.; 2011.

[5] European Commision. Roadmap to a Single European Transport Area - Towards a competitive and resource efficient transport system. White paper; 2011. Available from: http://eur-lex.europa.eu/legal-content/EN/ TXT/PDF/?uri=CELEX:52011DC0144\&from=EN

[6] Št'astná M, Vaishar A, Stonawská K. Integrated Transport System of the South-Moravian Region and its impact on rural development. Transp Res Part D Transp Environ. 2015;36: 53-64.

[7] Li CB, Chen WD, Jia HF. Study on the Development Mode of Integrated Passenger Transport in City. Appl Mech Mater. 2013;361-363: 2040-4.

[8] Štastná M, Vaishar A. The relationship between public transport and the progressive development of rural areas. Land use policy. 2017;67(May): 107-14.

[9] Šipuš D, Abramović B. The Possibility of Using Public Transport in Rural Area. Procedia Eng. 2017;192: 788-93.

[10] Kopecká P, Švetak J. The Integrated Public transport system. Sci J Marit Res. 2013;1: 149-56.

[11] Čejka J, Bartuška L, Turinská L. Possibilities of Using Transport Terminals in South Bohemian Region. Open Eng. 2017;7(1): 55-9.

[12] Filipović S, Tica S, Živanović P, Milovanović B. Comparative analysis of the basic features of the expected and perceived quality of mass passenger public transport service in Belgrade. Transport. 2009;24(4): 265-73.

[13] Sumaedi S, Bakti IGMY, Rakhmawati T, Astrini NJ, Widianti T, Yarmen M. Factors influencing public transport passengers' satisfaction: a new model. Manag Environ Qual An Int J. 2016;27(5): 585-97.

[14] Stopka O, Bartuška L, Kampf R. Passengers' Evaluation of the Integrated Transport Systems. Naše more. 2015;62(SI): 153-7.

[15] Reis V, Macario R. Promoting integrated passenger transport solutions using a business approach. Case Stud Transp Policy. 2015;3(1): 66-77.

[16] Borndörfer R, Karbstein M, Pfetsch ME. Models for fare planning in public transport. Discret Appl Math. 2012;160(18): 2591-605.

[17] Huang D, Liu Z, Liu P, Chen J. Optimal transit fare and service frequency of a nonlinear origin destination based fare structure. Transp Res Part E. 2016;96: 1-19.

[18] Drdla P, Bulíček J. Fare collection system in integrated public passenger transport systems. Perner's Contacts. 2012; VII(2): 22-33.

[19] Bouteiller C, Faivre d'Arcier B. How fare simulation tools in urban public transport can benefit from smart card data analysis? CUPUM 2015; 2015. 
[20] Koháni M. Tariff Zones Design in Integrated Transport Systems: A case study for the Žilina Municipality. Mech Energy, Environ. 2015; 91-7.

[21] Koháni M. Exact approach to the tariff zones design problem in public transport. Proceedings of the $30^{\text {th }}$ International Conference Mathematical Methods in Economics, Sep 11-13 2012, Karviná, Czech Republic. Silesian University in Opava, School of Business Administration in Karviná; 2012. p. 426-31.

[22] Hamacher HW, Schöbel A. Design of Zone Tariff Systems in Public Transportation. Berichte des Fraunhofer ITWM. 2001;21(21).

[23] Jansson K. Optimal public transport price and service frequency. J Transp Econ Policy. 1993.

[24] Chen XM, Yin M, Song M, Zhang L, Li M. Social Welfare Maximization of Multimodal Transportation. Transp
Res Rec J Transp Res Board. 2014;(2451): 36-49.

[25] Holmgren J. A strategy for increased public transport usage - The effects of implementing a welfare maximizing policy. Res Transp Econ. 2014;48: 221-6.

[26] Guzman LA, de la Hoz D, Circella G. Evaluation of synergies from transportation policy packages using a social welfare maximization approach: A case study for Madrid, Spain. Case Stud Transp Policy. 2015;3: 99-110.

[27] Houston D, Tilley S. Fare's fair? Concessionary travel policy and social justice. J Poverty Soc Justice. 2015;24(2): 187-207.

[28] Gašparović S. Theoretical postulates of transport disadvantage. Hrvat Geogr Glas. 2016;78(1): 73-95.

[29] Martens K. Transport Justice: Designing Fair Transportation Systems. New York: Routledge; 2017. 240 p. 